\title{
ANALISIS KEBUTUHAN SARANA DAN PRASARANA PEMUKIMAN PADA KECAMATAN TELLUWANUA KOTA PALOPO
}

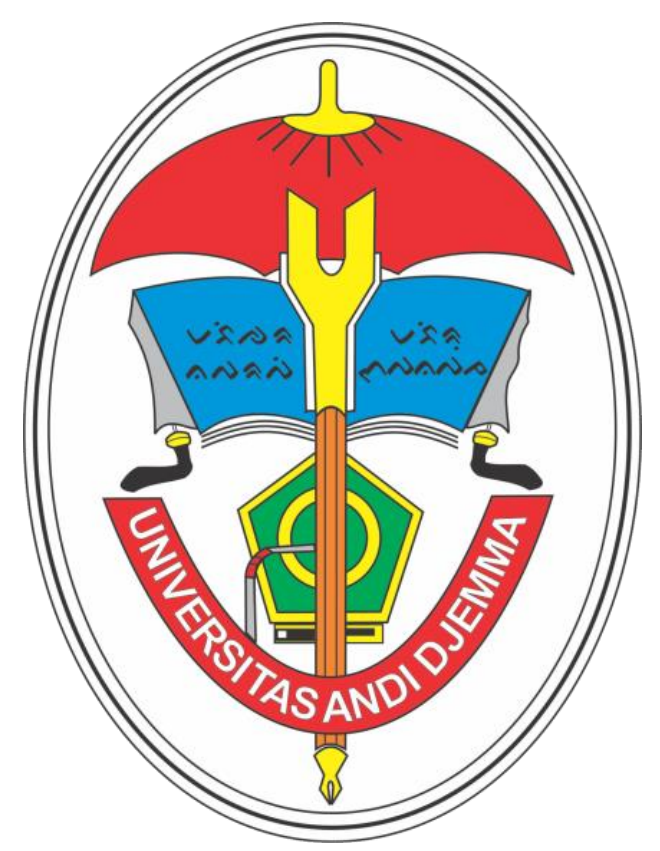

DISUSUN OLEH:

KELOMPOK 1

SYAHRIL

SIPRIANUS BERTRAND XAVERIAN MOHD HIKMAH HIDAYAT ABD. TEGAR
20.023.22.201.075 20.023.22.201.076 20.023.22.201.077 20.023.22.201.092

FAKULTAS TEKNIK JURUSAN SIPIL UNIVERSITAS ANDI DJEMMA 2021 


\section{KATA PENGANTAR}

Puji dan syukur kita panjatkan kepada Tuhan Yang Maha Esa. Karena, berkat limpahan dan rahmat-Nya, kami selaku penyusun dapat menyelesaikan laporan ini guna mengetahui sebagai pembelajaran dan untuk memenuhi tugas mata kuliah Perencanaan Wilayah dan Kota.

Kami menyadari bahwa laporan ini masih banyak kekurangan dan jauh dari kata sempurna. Untuk itu, kepada dosen pembimbing kami meminta masukannya demi perbaikan laporan yang lebih baik dan mengharapkan kritik serta saran yang membangun dari para pembaca.

Akhir kata kami selaku penyusun mengucapkan terimakasih.

Walenrang, 24 Januari 2022

Penyusun 


\section{DAFTAR ISI}

KATA PENGANTAR .................................................................................... ii

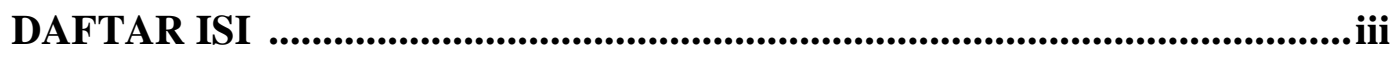

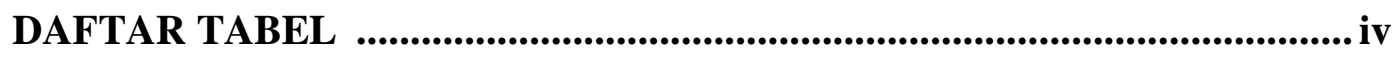

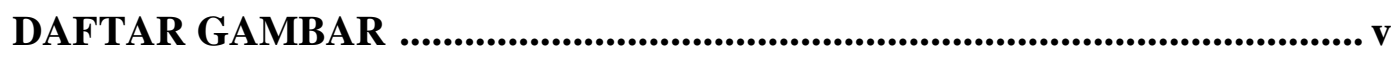

BAB I PENDAHULUAN .................................................................... 1

1.1 Latar Belakang ..................................................................... 1

1.2 Maksud dan Tujuan.............................................................. 1

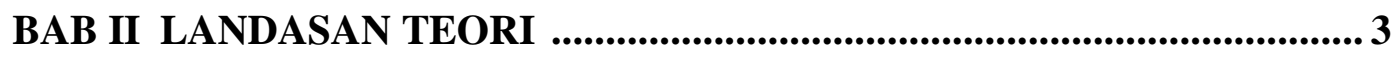

2.1 Tinjauan Umum ............................................................. 3

2.2 Standar Sarana dan Prasarana Wilayah..................................... 4

BAB IIIPEMBAHASAN ............................................................................ 15

3.1 Gambaran Umum Wilayah................................................. 15

3.2 Jumlah Penduduk 5 Tahun Terakhir .................................... 15

3.3 Jumlah Fasilitas Pendidikan, Ekonomi dan Kesehatan................ 16

3.4 Proyeksi Penduduk 20 Tahun yang akan datang ....................... 16

3.5 Kebutuhan Sarana dan Prasarana 20 tahun yang akan datang...... 17

BAB IV PENUTUP ................................................................................ 20

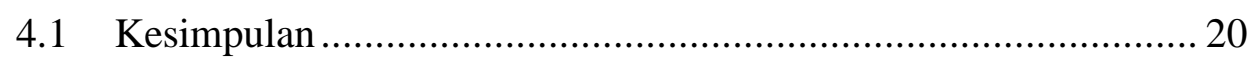

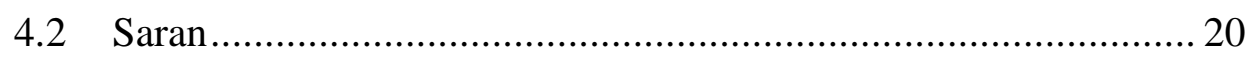

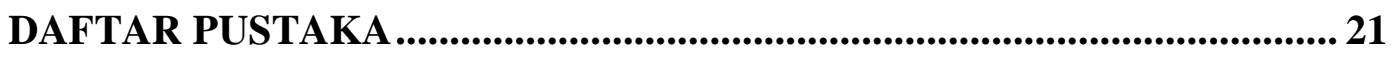




\section{DAFTAR TABEL}

Tabel 2.1 Kebutuhan Program Ruang Minimum …..................................8

Tabel 2.2 Kebutuhan Sarana Pendidikan Dan Pembelajaran................... 8

Tabel 2.3 Pembakuan Tipe SD/MI, SLTP/Mts \& SMU ............................. 9

Tabel 2.4 Kebutuhan ruang belajar pada SD/MI, SLTP/MTs \& SMU .... 9

Tabel 2.5 Kebutuhan Luas Lantai dan Lahan Sarana Pendidikan Menurut Tipe Sekolah ........................................................... 10

Tabel 2.6 Jenis Sarana Perdagangan dan Niaga ....................................... 12

Tabel 2.7 Kebutuhan Sarana Kesehatan ................................................ 14

Tabel 3.1 Jumlah Penduduk 5 Tahun Terakhir.......................................... 15

Tabel 3.2 Jumlah Fasilitas Pedidikan ............................................................... 16

Tabel 3.3 Jumlah Fasilitas Ekonomi........................................................ 16

Tabel 3.4 Jumlah Fasilitas Kesehatan ..................................................... 16

Tabel 3.5 Proyeksi Penduduk 20 Tahun yang Akan Datang ..................... 16

Tabel 3.6 Kebutuhan Sarana Pendidikan ditahun 2025 ........................... 17

Tabel 3.7 Kebutuhan Sarana Pendidikan ditahun 2030 ........................... 17

Tabel 3.8 Kebutuhan Sarana Pendidikan ditahun 2035.......................... 17

Tabel 3.9 Kebutuhan Sarana Pendidikan ditahun 2040 .......................... 17

Tabel 3.10 Kebutuhan Sarana Ekonomi ditahun 2025............................... 18

Tabel 3.11 Kebutuhan Sarana Ekonomi ditahun 2030............................ 18

Tabel 3.12 Kebutuhan Sarana Ekonomi ditahun 2035.............................. 18

Tabel 3.13 Kebutuhan Sarana Ekonomi ditahun 2040............................... 18

Tabel 3.14 Kebutuhan Sarana Kesehatan ditahun 2025............................ 19

Tabel 3.15 Kebutuhan Sarana Kesehatan ditahun 2030............................. 19

Tabel 3.16 Kebutuhan Sarana Kesehatan ditahun 2035.............................. 19

Tabel 3.17 Kebutuhan Sarana Kesehatan ditahun 2040............................. 19 


\section{DAFTAR GAMBAR}

Gambar 3.1 Sketsa Peta Kecamatan Walenrang............................................ 15 


\begin{abstract}
ABSTRAK
Paper ini membahas bagaimana kebutuhan sarana dan prasarana di kecamatan TELLUWANUA kota PALOPO. Fokus utamanya adalah pada sarana pendidikan, kesehatan dan perekonomian. Paper ini juga merupakan tugas mata kuliah PERENCANAAN WILAYAH DAN KOTA.
\end{abstract}




\section{BAB I \\ PENDAHULUAN}

\subsection{Latar Belakang}

Pertumbuhan (Growth) merupakan ukuran utama keberhasilan pembangunan, dan hasil pertumbuhan ekonomi akan dapat dinikmati masyarakat sampai dilapisan paling bawah, baik dengan dirinya sendiri maupun dengan campur tangan pemerintah. Pertumbuhan harus berjalan beriringan dan terencana, mengupayakan pemerataan kesempatan dan pembagia hasil-hasil pembangunan dengan terciptanya lebih merata. Dengan demikian maka daerah yang miskin, tertinggal, tidak produktif akan menjadi produktif, yang akhirnya akan mempercepat pertumbuhan itu sendiri. Strategi ini dikenal dengan istilah "redistribusi with growth".

Pertumbuhan ekonomi daerah yang berbeda-beda intensitasnya akan menyebabkan terjadinya gangguan ekonomi dan pendapatan antar daerah. Kecamatan Walenrang harus dapat memenuhi sarana prasarana untuk dapat melayani masyarakat secara optimal. Untuk mendukung pertumbuhan, pembangunan dan mengurangi kejadian-ketimpangan serta memberikan pelayanan pada masyarakat perlu diamati selama siklus ekonomi sedang berlangsung sinyalemen positif atau negatif sehingga mempengaruhi kinerja ekonomi makro secara umum dapat mempengaruhi fasilitas pendidikan dan kesehatan yang memadai. Kecamatan Walenrang harus memiliki sarana dan prasarana untuk dapat melayani masyrakat, baik dari segi pendidikan, ekonoomi maupun dari segi kesehatan berdasarkan pertumbuhan jumlah penduduk. 


\subsection{Maksud dan Tujuan}

Bertitik tolak dari latar belakang Kecamatan Telluwanua, maka tujuan dari penelitian ini bertujuan sebagai berikut:

1. Menggambarkan keadaan wilayah pusat pertumbuhan di Kecamatan Telluawanua Kota Palopo.

2. Untuk menganalisis kebutuhan pengembangan penyediaan prasarana pendidikan, kesehatan pada wilayah pusat pertumbuhan di Kecamatan Telluwamua Kota Palopo sampai tahun 2042. 


\section{BAB II \\ LANDASAN TEORI}

\subsection{Tinjauan Umum}

Sarana dan prasarana merupakan kebutuhan dasar dari suatu area pemukiman (Fisu, 2018). Pemenuhan sarana dan prasarana tidak hanya untuk memenuhi kebutuhan permukiman, namun jga dapat meningkatkan perekonomian penduduk (Fisu, 2020)

Prasarana adalah kelengkapan dasar fisik suatu lingkungan, kawasan, kota atau wilayah (spatial space) sehingga memungkinkan ruang tersebut berfungsi sebagaimana mestinya. Infrastuktur metujuk pada sistem fisik yang menyediakan transportasi, pengairan, drainase, bangunan-bangunan gedung dan fasilitas publik yang lain yang dibutuhkan untuk memenuhi kebutuhan dasar manusia dalam lingkup sosial dan ekonomi (Grigg,1988 dalam Kodoatie,2005:8). Sementara itu adapun pengertian prasarana menurut Jayadinata (1992 dalam Juliawan,2015:5) prasarana merupakan suatu faktor potensial yang sangat penting dalam menentukan arah dan masa depan perkembangan suatu wilayah, karena pembangunan tidak akan sukses dan berjalan dengan baik tanpa dukungan prasarana yang memadai, prasarana kota merupakan fasilitas umum yang menjadi penunjang utama terselenggaranya suatu proses atau kegiatan dalam kota yang pada akhirnya akan menentukan perkembangan kota. Dengan demikian prasarana kota merupakan fasilitas umum yang menjadi penunjang utama terselenggaranya suatu proses atau kegiatan dalam kota, yang padxa akhirnya akan menentukan perkembangan kota.

Prasarana lingkungan merupakan kelengkapan dasar fisik lingkungan yang memungkinkan lingkungan dapat berfungsi sebagaimana mestinya, lebih jelasnya prasarana lingkungan atau sarana yang utama bagi berfungsinya suatu lingkungan permukiman adalah jaringan jalan untuk mobilitas orang dan angkutan barang, mencegah perambatan kebakaran serta untuk menciptakan ruang dan bangunan yang teratur, jaringan air bersih, jaringan saluran pembuangan air limbah dan 
tempat pembuangan sampah untuk kesehatan lingkungan, serta jaringan saluran air hujan untuk pematusan (drainase) dan pencegah banjir setempat.

Fungsi prasarana adalah untuk melayani dan mendorong terwujudnya lingkungan permukiman dan lingkungan usaha yang optimal sesuai dengan fungsinya, upaya memperbaiki lingkungan membutuhkan keseimbangan antar tingkat kebutuhan masyarakat (Diwiryo,1996 dalam Juliawan, 2015:6) 22.

Dari pengertian tersebut dapat disederhanakan bahwa prasarana merupakan kerangka dasar dari suatu sistem, kerangka dasar tersebut menjadi fasilitas umum dan pelengkapan dasar fisik yang memungkinkan lingkungan untuk berfungsi sebagaimana mestinya, serta menjadi penentu keberhasilan daru suatu perkembangan kota.

Sebagai salah satu konsep pola pikir di bawah ini diilustrasikan diagram sederhana bagaimana peran infrastruktur. Diagram ini menunjukan bahwa secara ideal lingkungan alam merupakan pendukung dari sistem infrastruktur, dan sistem ekonomi didukung oleh sistem infrastruktur. Sistem sosial sebagai obyek dan sasaran didukung oleh sistem ekonomi.

\subsection{Standar Sarana dan Prasarana Wilayah}

Standar Nasional Indonesia (SNI 03-1733-2004) yang dikeluarkan oleh BSN tentang Tata cara perencanaan lingkungan perumahan di perkotaan ini disusun oleh Panitia Teknik Konstruksi dan Bangunan. Standar ini memuat uraian detail prinsip-prinsip perencanaan lingkungan perumahan di perkotaan, yang disusun sebagai revisi dari SNI 03-1733-1989 tentang Tata cara perencanaan lingkungan perumahan di perkotaan.

Standar ini disusun melalui konsensus di Bandung pada tanggal 17 Juni 2003, yang dihadiri oleh stakholder terkait. Apabila dalam penerapan standar ini terdapat hal-hal yang meragukan, diharapkan dapat membandingkan secara langsung dengan substansi yang terdapat dalam acuan tersebut, atau dengan edisi yang terakhir, kecuali hal-hal yang disesuaikan dengan kondisi Indonesia.

Standar Nasional Indonesia Tata cara perencanaan lingkungan perumahan di perkotaan adalah panduan (dokumen nasional) yang berfungsi sebagai kerangka 
acuan untuk perencanaan, perancangan, penaksiran biaya dan kebutuhan ruang, serta pelaksanaan pembangunan perumahan dan permukiman.

\subsubsection{Sarana Pendidikan dan Pembelajaran}

\section{1) Deskripsi Umum}

Dasar penyediaan sarana pendidikan adalah untuk melayani setiap unit administrasi pemerintahan baik yang informal (RT, RW) maupun yang formal (Kelurahan, Kecamatan), dan bukan didasarkan semata-mata pada jumlah penduduk yang akan dilayani oleh sarana tersebut. Dasar penyediaan sarana pendidikan ini juga mempertimbangkan pendekatan desain keruangan unit-unit atau kelompok lingkungan yang ada. Tentunya hal ini dapat terkait dengan bentukan grup bangunan/blok yang nantinya terbentuk sesuai konteks lingkungannya. Sedangkan penempatan penyediaan fasilitas ini akan mempertimbangkan jangkauan radius area layanan terkait dengan kebutuhan dasar sarana yang harus dipenuhi untuk melayani pada area tertentu.

Perencanaan sarana pendidikan harus didasarkan pada tujuan pendidikan yang akan dicapai, dimana sarana pendidikan dan pembelajaran ini akan menyediakan ruang belajar harus memungkinkan siswa untuk dapat mengembangkan pengetahuan, keterampilan, serta sikap secara optimal. Oleh karena itu dalam merencanakan sarana pendidikan harus memperhatikan:

a) berapa jumlah anak yang memerlukan fasilitas ini pada area perencanaan;

b) optimasi daya tampung dengan satu shift;

c) effisiensi dan efektifitas kemungkinan pemakaian ruang belajar secara terpadu;

d) pemakaian sarana dan prasarana pendukung;

e) keserasian dan keselarasan dengan konteks setempat terutama dengan berbagai jenis sarana lingkungan lainnya. 


\section{2) Jenis Sarana}

Sarana pendidikan yang diuraikan dalam standar ini hanya menyangkut bidang pendidikan yang bersifat formal / umum, yaitu meliputi tingkat prabelajar (Taman Kanak-kanak); tingkat dasar (SD/MI); tingkat menengah (SLTP/MTs dan SMU). SNI 03-1733200425 dari 52.

Adapun penggolongan jenis sarana pendidikan dan pembelajaran ini meliputi:

a) taman kanak-kanak (TK), yang merupakan penyelenggaraan kegiatan belajar dan mengajar pada tingkatan pra belajar dengan lebih menekankan pada kegiatan bermain, yaitu $75 \%$, selebihnya bersifat pengenalan;

b) sekolah dasar (SD), yang merupakan bentuk satuan pendidikan dasar yang menyelenggarakan program enam tahun;

c) sekolah lanjutan tingkat pertama (SLTP), yang merupakan bentuk satuan pendidikan dasar yang menyelenggarakan proram tiga tahun sesudah sekolah dasar (SD);

d) sekolah menengah umum (SMU), yang merupakan satuan pendidikan yang menyelenggarakan program pendidikan menengah mengutamakan perluasan pengetahuan dan peningkatan keterampilan siswa untuk melanjutkan pendidikan ke jenjang pendidikan tinggi;

e) sarana pembelajaran lain yang dapat berupa taman bacaan ataupun perpustakaan umum lingkungan, yang dibutuhkan di suatu lingkungan perumahan sebagai sarana untuk meningkatkan minat membaca, menambah ilmu pengetahuan, rekreasi serta sarana penunjang pendidikan. 


\section{3) Kebutuhan Ruang dan Lahan}

Berbagai pertimbangan yang harus diperhatikan pada penentuan kebutuhan ruang dan lahan adalah:

a) Penyediaan jumlah sarana pendidikan dan pembelajaran yang harus disediakan didasarkan pada Tabel 9.

b) Kebutuhan sarana pendidikan prabelajar serta pendidikan tingkat dasar dan menengah, harus direncanakan berdasarkan perhitungan proyeksi jumlah siswa dengan cara sebagaimana Rumus 2, Rumus 3, Rumus 4 dan Rumus 5, yang akan menentukan tipe sekolah serta kebutuhan jumlah ruang, luas ruang dan luas lahan. Rumus 2, Rumus 3, Rumus 4 dan Rumus 5 , dipergunakan juga untuk menghitung penambahan ruangruang belajar pada sekolah-sekolah yang sudah ada.

c) Perencanaan kebutuhan ruang dan lahan untuk sarana pendidikan didasarkan tipe masing-masing sekolah yang dibedakan menurut:

1) jumlah rombongan belajar;

2) jumlah peserta didik;

3) jumlah tenaga kependidikan; kepala sekolah, wakil kepala sekolah, guru, dan tenaga tata usaha;

4) kebutuhan ruang belajar, ruang kantor, dan ruang penunjang;

5) luas tanah, dan lingkungan/lokasi sekolah.

d) Kebutuhan luas lantai dan lahan untuk masing-masing sarana pendidikan tergantung pada tipe sekolah untuk masing-masing tingkatan pendidikan. Untuk perencanaan bangunan SMU, mengacu pada SNI-03-1730-2002 tentang Tata cara perencanaan bangunan gedung sekolah menengah umum. Dasar penyediaan ini juga akan mempertimbangkan pendekatan desain keruangan unit-unit atau kelompok 
lingkungan yang ada beserta posisi pusat lingkungan yang ada.

Tentunya hal ini dapat terkait dengan bentukan grup bangunan /

blok yang nantinya lahir sesuai konteks lingkungannya.

Tabel 2.1 Kebutuhan program ruang minimum

\begin{tabular}{|c|c|c|}
\hline No. & Jenis Sarana & Program Ruang \\
\hline 1. & $\begin{array}{l}\text { Taman Kanak- } \\
\text { kanak }\end{array}$ & $\begin{array}{l}\text { Memiliki minimum } 2 \text { ruang kelas @ 25-30 } \\
\text { murid. Dilengkapi dengan ruang-ruang lain } \\
\text { dan ruang terbuka/bermain } \pm 700 \mathrm{~m}^{2}\end{array}$ \\
\hline 2. & Sekolah Dasar & \multirow{3}{*}{$\begin{array}{l}\text { Memiliki minimum } 6 \text { ruang kelas @ } 40 \text { murid } \\
\text { Dilengkapi dengan ruang-ruang lain dan } \\
\text { ruang terbuka / bermain } \pm 3000-7000 \mathrm{~m}^{2}\end{array}$} \\
\hline 3. & SLTP & \\
\hline 4. & SMU & \\
\hline 5. & Taman Bacaan & Memiliki minimum 1 ruang baca @ 15 murid \\
\hline
\end{tabular}

CATATAN Acuan diambil dari SNI 03-1733-1989, Tata cara perencanaan kawasan perumahan kota.

Tabel 2.2 Kebutuhan sarana pendidikan dan pembelajaran

\begin{tabular}{|c|c|c|c|c|c|c|c|c|}
\hline \multirow[b]{2}{*}{ No. } & \multirow[b]{2}{*}{$\begin{array}{l}\text { Jenis } \\
\text { Sarana }\end{array}$} & \multirow{2}{*}{$\begin{array}{c}\text { Jumlah } \\
\text { Penduduk } \\
\text { pendukung } \\
\text { (jiwa) }\end{array}$} & \multicolumn{2}{|c|}{$\begin{array}{l}\text { Kebutuhan Per } \\
\text { Satuan Sarana }\end{array}$} & \multirow[b]{2}{*}{$\begin{array}{l}\text { Standard } \\
\left(\mathrm{m}^{2} / \text { jiwa }\right)\end{array}$} & \multicolumn{2}{|c|}{ Kriteria } & \multirow[b]{2}{*}{ Keterangan } \\
\hline & & & $\begin{array}{l}\text { Luas } \\
\text { Lantai } \\
\text { Min. } \\
\left(\mathrm{m}^{2}\right) \\
\end{array}$ & $\begin{array}{l}\text { Luas } \\
\text { Lahan } \\
\text { Min. } \\
\left(\mathrm{m}^{2}\right)\end{array}$ & & $\begin{array}{c}\text { Radius } \\
\text { pencapaian }\end{array}$ & $\begin{array}{l}\text { Lokasi dan } \\
\text { Penyelesaian }\end{array}$ & \\
\hline 1. & $\begin{array}{l}\text { Taman } \\
\text { Kanak- } \\
\text { kanak }\end{array}$ & 1.250 & $\begin{array}{r}216 \\
\text { termasuk } \\
\text { rumah } \\
\text { penjaga } \\
36 \mathrm{~m} 2\end{array}$ & 500 & 0,28 m2/j & $500 \mathrm{~m}^{\prime}$ & \multirow{2}{*}{$\begin{array}{l}\text { Di tengah } \\
\text { kelompok warga. } \\
\text { Tidak } \\
\text { menyeberang } \\
\text { jalan raya. } \\
\text { Bergabung } \\
\text { dengan taman } \\
\text { sehingga terjadi } \\
\text { pengelompokan } \\
\text { kegiatan. }\end{array}$} & $\begin{array}{l}2 \text { rombongan } \\
\text { prabelajar @ } 60 \\
\text { murid dapat } \\
\text { bersatu dengan } \\
\text { sarana lain }\end{array}$ \\
\hline 2. & $\begin{array}{l}\text { Sekolah } \\
\text { Dasar }\end{array}$ & 1.600 & 633 & 2.000 & 1,25 & $1.000 \mathrm{~m}^{\prime}$ & & \multirow{4}{*}{$\begin{array}{l}\text { Kebutuhan harus } \\
\text { berdasarkan } \\
\text { perhitungan } \\
\text { dengan rumus 2, } \\
3 \text { dan } 4 \text {. } \\
\text { Dapat digabung } \\
\text { dengan sarana } \\
\text { pendidikan lain, } \\
\text { mis. SD, SMP, } \\
\text { SMA dalam satu } \\
\text { komplek }\end{array}$} \\
\hline 3. & SLTP & 4.800 & 2.282 & 9.000 & 1,88 & $1.000 \mathrm{~m}^{\prime}$ & \multirow{2}{*}{$\begin{array}{l}\text { Dapat dijangkau } \\
\text { dengan } \\
\text { kendaraan umum. } \\
\text { Disatukan dengan } \\
\text { lapangan olah } \\
\text { raga. } \\
\text { Tidak selalu harus } \\
\text { di pusat } \\
\text { lingkungan. } \\
\end{array}$} & \\
\hline 4. & SMU & 4.800 & 3.835 & 12.500 & 2,6 & $3.000 \mathrm{~m}^{\prime}$ & & \\
\hline 5. & $\begin{array}{l}\text { Taman } \\
\text { Bacaan }\end{array}$ & 2.500 & 72 & 150 & 0,09 & $1.000 \mathrm{~m}^{\prime}$ & $\begin{array}{l}\text { Di tengah } \\
\text { kelompok warga } \\
\text { tidak menyebe- } \\
\text { rang jalan } \\
\text { lingkungan. }\end{array}$ & \\
\hline
\end{tabular}

CATATAN Acuan diambil dari SNI 03-1733-1989, Tata cara perencanaan kawasan perumahan kota. 
Tabel 2.3 Pembakuan tipe SD/MI, SLTP/MTs dan SMU

\begin{tabular}{|c|c|c|c|c|}
\hline $\begin{array}{c}\text { Tingkat } \\
\text { Pendidikan }\end{array}$ & $\begin{array}{c}\text { Tipe } \\
\text { Sekolah }\end{array}$ & $\begin{array}{c}\text { Rombongan } \\
\text { Belajar }\end{array}$ & $\begin{array}{l}\text { Peserta Didik } \\
\text { (siswa) }\end{array}$ & Lokasi \\
\hline \multirow{3}{*}{$\mathrm{SD} / \mathrm{MI}$} & Tipe A & 12 & 480 & \multirow{9}{*}{$\begin{array}{c}\text { Dekat dengan } \\
\text { lokasi ruang } \\
\text { terbuka } \\
\text { lingkungan }\end{array}$} \\
\hline & Tipe B & 9 & 360 & \\
\hline & Tipe C & 6 & 240 & \\
\hline \multirow{3}{*}{ SLTP/MTs } & Tipe A & 27 & 1.080 & \\
\hline & Tipe B & 18 & 720 & \\
\hline & Tipe C & 9 & 360 & \\
\hline \multirow{3}{*}{ SMU } & Tipe A & 27 & 1.080 & \\
\hline & Tipe B & 18 & 720 & \\
\hline & Tipe C & 9 & 360 & \\
\hline
\end{tabular}

CATATAN Acuan diambil dari SNI 03-1733-1989, Tata cara perencanaan kawasan perumahan kota.

Tabel 2.4 Kebutuhan ruang belajar pada SD/MI, SLTP/MTs \& SMU

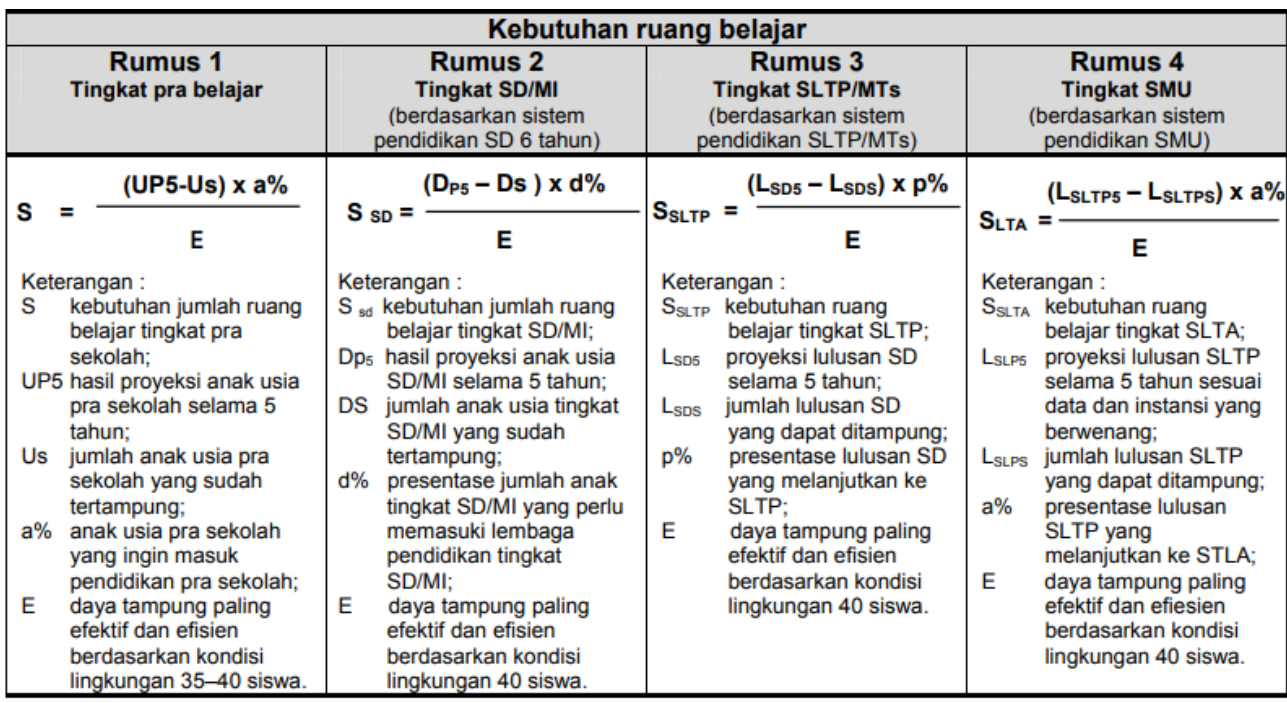

CATATAN Acuan diambil dari SNI 03-1733-1989, Tata cara perencanaan kawasan perumahan kota. 
Tabel 2.5 Kebutuhan luas lantai dan lahan sarana pendidikan menurut tipe sekolah

\begin{tabular}{|c|c|c|c|c|c|}
\hline $\begin{array}{c}\text { Tingkat } \\
\text { Pendidikan }\end{array}$ & $\begin{array}{c}\text { Tipe } \\
\text { Sekolah }\end{array}$ & $\begin{array}{c}\text { Rombongan } \\
\text { Belajar } \\
\text { (rombongan) }\end{array}$ & $\begin{array}{c}\text { Peserta } \\
\text { Didik } \\
\text { (siswa) }\end{array}$ & $\begin{array}{c}\text { Luas Ruang } \\
\text { Minimum } \\
\left(\mathrm{m}^{2}\right)\end{array}$ & $\begin{array}{c}\text { Luas Lahan } \\
\text { Minimum } \\
\left(\mathrm{m}^{2}\right)\end{array}$ \\
\hline \multirow{3}{*}{ SD/MI } & $\bar{T}$ Tipe A & 12 & 480 & 1.000 & 3.000 \\
\hline & Tipe B & 9 & 360 & 633 & 2.000 \\
\hline & Tipe C & 6 & 240 & 251 & 1.000 \\
\hline \multirow{3}{*}{ SLTP/MTs } & Tipe A & 27 & 1.080 & 3.077 & 9.000 \\
\hline & Tipe B & 18 & 720 & 2.282 & 9.000 \\
\hline & Tipe C & 9 & 360 & 1.502 & 6.000 \\
\hline \multirow{7}{*}{ SMU } & \multirow{3}{*}{ Tipe A } & \multirow{3}{*}{27} & \multirow{3}{*}{1.080} & \multirow{3}{*}{5.233} & 1 lantai: 15.000 \\
\hline & & & & & 2 lantai: 9.500 \\
\hline & & & & & 3 lantai: 7.000 \\
\hline & \multirow{3}{*}{ Tipe B } & \multirow{3}{*}{18} & \multirow{3}{*}{720} & \multirow{3}{*}{3.835} & 1 lantai: 12.500 \\
\hline & & & & & 2 lantai: 8.000 \\
\hline & & & & & 3 lantai: 5.000 \\
\hline & Tipe C & 9 & 360 & 2.692 & 10.000 \\
\hline
\end{tabular}

CATATAN Acuan diambil dari SNI 03-1733-1989, Tata cara perencanaan kawasan perumahan kota.

\subsubsection{Sarana Perdagangan dan Niaga}

\section{1) Deskripsi Umum}

Sarana perdagangan dan niaga ini tidak selalu berdiri sendiri dan terpisah dengan bangunan sarana yang lain. Dasar penyediaan selain berdasarkan jumlah penduduk yang akan dilayaninya, juga mempertimbangkan pendekatan desain keruangan unit-unit atau kelompok lingkungan yang ada. Tentunya hal ini dapat terkait dengan bentukan grup bangunan / blok yang nantinya terbentuk sesuai konteks lingkungannya. Sedangkan penempatan penyediaan fasilitas ini akan mempertimbangkan jangkauan radius area layanan terkait dengan kebutuhan dasar sarana yang harus dipenuhi untuk melayani pada area tertentu.

\section{2) Jenis Sarana}

Kebutuhan ruang dan lahan untuk sarana ini akan berkaitan juga dengan daya dukung lingkungan dan jalan yang ada di sekitar 
bangunan sarana tersebut. Besaran kebutuhan ruang dan lahan menurut penggolongan jenis sarana perdagangan dan niaga adalah:

a) warung / toko Luas lantai yang dibutuhkan $\pm 50 \mathrm{~m} 2$ termasuk gudang kecil. Apabila merupakan bangunan tersendiri (tidak bersatu dengan rumah tinggal), luas tanah yang dibutuhkan adalah $100 \mathrm{~m} 2$.

b) pertokoan (skala pelayanan untuk 6.000 penduduk) Luas lantai yang dibutuhkan $1.200 \mathrm{~m} 2$. Sedangkan luas tanah yang dibutuhkan $3.000 \mathrm{~m} 2$. Bangunan pertokoan ini harus dilengkapi dengan:

1) tempat parkir kendaraan umum yang dapat dipakai bersama kegiatan lain pada pusat lingkungan;

2) sarana-sarana lain yang erat kaitannya dengan kegiatan warga;

3) pos keamanan.

c) pusat pertokoan dan atau pasar lingkungan (skala pelayanan unit kelurahan $\approx 30.000$ penduduk) Luas tanah yang dibutuhkan: $10.000 \mathrm{~m} 2$. Bangunan pusat pertokoan / pasar lingkungan ini harus dilengkapi dengan:

1) tempat parkir umum, sudah termasuk kebutuhan luas tanah;

2) terminal kecil atau pangkalan untuk pemberhentian kendaraan;

3) pos keamanan;

4) sistem pemadam kebakaran;

5) musholla/tempat ibadah.

d) pusat perbelanjaan dan niaga (skala pelayanan unit kelurahan $\approx$ 120.000 penduduk) Luas tanah yang dibutuhkan adalah 36.000 $\mathrm{m} 2$. Bangunan pusat perbelanjaan harus dilengkapi:

1) tempat parkir umum, sudah termasuk kebutuhan luas tanah;

2) terminal atau pangkalan untuk pemberhentian kendaraan;

3) pos keamanan; 
4) sistem pemadam kebakaran;

5) musholla/tempat ibadah.

Tabel 2.6 Jenis sarana perdagangan dan niaga

\begin{tabular}{|c|c|c|c|c|c|c|c|}
\hline \multirow[b]{2}{*}{ No. } & \multirow[b]{2}{*}{ Jenis Sarana } & \multirow{2}{*}{$\begin{array}{l}\text { Jumlah } \\
\text { Penduduk } \\
\text { pendukung } \\
\text { (jiwa) }\end{array}$} & \multicolumn{2}{|c|}{$\begin{array}{l}\text { Kebutuhan Per } \\
\text { Satuan Sarana }\end{array}$} & \multirow[b]{2}{*}{$\begin{array}{l}\text { Standard } \\
\left(\mathrm{m}^{2} / \text { jiwa }\right)\end{array}$} & \multicolumn{2}{|c|}{ Kriteria } \\
\hline & & & $\begin{array}{l}\text { Luas } \\
\text { Lantai } \\
\text { Min. } \\
\left(\mathrm{m}^{2}\right) \\
\end{array}$ & $\begin{array}{l}\text { Luas } \\
\text { Lahan } \\
\text { Min. } \\
\left(\mathrm{m}^{2}\right) \\
\end{array}$ & & $\begin{array}{c}\text { Radius } \\
\text { pencapaian }\end{array}$ & $\begin{array}{l}\text { Lokasi dan } \\
\text { Penyelesaian }\end{array}$ \\
\hline 1. & $\begin{array}{l}\text { Toko I } \\
\text { Warung }\end{array}$ & 250 & $\begin{array}{r}50 \\
\text { (termasuk } \\
\text { gudang) }\end{array}$ & $\begin{array}{r}100 \\
\text { (bila } \\
\text { berdiri } \\
\text { sendiri) }\end{array}$ & 0,4 & $300 \mathrm{~m}^{\prime}$ & $\begin{array}{l}\text { Di tengah } \\
\text { kelompok tetangga. } \\
\text { Dapat merupakan } \\
\text { bagian dari sarana } \\
\text { lain }\end{array}$ \\
\hline 2. & Pertokoan & 6.000 & 1.200 & 3.000 & 0,5 & $2.000 \mathrm{~m}^{\prime}$ & $\begin{array}{l}\text { Di pusat kegiatan } \\
\text { sub lingkungan. } \\
\text { KDB } 40 \% \text { Dapat } \\
\text { berbentuk P\&D }\end{array}$ \\
\hline 3. & $\begin{array}{l}\text { Pusat } \\
\text { Pertokoan + } \\
\text { Pasar } \\
\text { Lingkungan }\end{array}$ & 30.000 & 13.500 & 10.000 & 0,33 & & $\begin{array}{l}\text { Dapat dijangkau } \\
\text { dengan kendaraan } \\
\text { umum }\end{array}$ \\
\hline 4. & $\begin{array}{l}\text { Pusat } \\
\text { Perbelanjaan } \\
\text { dan Niaga } \\
\text { (toko + pasar } \\
+ \text { bank + } \\
\text { kantor) }\end{array}$ & 120.000 & 36.000 & 36.000 & 0,3 & & $\begin{array}{l}\text { Terletak di jalan } \\
\text { utama. } \\
\text { Termasuk sarana } \\
\text { parkir sesuai } \\
\text { ketentuan } \\
\text { setempat }\end{array}$ \\
\hline
\end{tabular}

CATATAN Acuan diambil dari SNI 03-1733-1989, Tata cara perencanaan kawasan perumahan kota.

\subsubsection{Sarana Kesehatan}

\section{1) Deskripsi Umum}

Sarana kesehatan berfungsi memberikan pelayanan kesehatan kesehatan kepada masyarakat, memiliki peran yang sangat strategis dalam mempercepat peningkatan derajat kesehatan masyarakat sekaligus untuk mengendalikan pertumbuhan penduduk. Dasar penyediaan sarana ini adalah didasarkan jumlah penduduk yang dilayani oleh sarana tersebut.

Dasar penyediaan ini juga akan mempertimbangkan pendekatan desain keruangan unit-unit atau kelompok lingkungan yang ada. Tentunya hal ini dapat terkait dengan bentukan grup bangunan/blok yang nantinya terbentuk sesuai konteks lingkungannya. Sedangkan penempatan penyediaan fasilitas ini akan mempertimbangkan jangkauan radius area layanan terkait dengan 
kebutuhan dasar sarana yang harus dipenuhi untuk melayani pada area tertentu.

\section{2) Jenis Sarana}

Beberapa jenis sarana yang dibutuhkan adalah:

a) posyandu yang berfungsi memberikan pelayanan kesehatan untuk anak-anak usia balita;

b) balai pengobatan warga yang berfungsi memberikan pelayanan kepada penduduk dalam bidang kesehatan dengan titik berat terletak pada penyembuhan (currative) tanpa perawatan, berobat dan pada waktu-waktu tertentu juga untuk vaksinasi;

c) balai kesejahteraan ibu dan anak (BKIA) / Klinik Bersalin), yang berfungsi melayani ibu baik sebelum, pada saat dan sesudah melahirkan serta melayani anak usia sampai dengan 6 tahun;

d) puskesmas dan balai pengobatan, yang berfungsi sebagai sarana pelayanan kesehatan tingkat pertama yang memberikan pelayanan kepada penduduk dalam penyembuhan penyakit, selain melaksanakan program pemeliharaan kesehatan dan pencegahan penyakit di wilayah kerjanya;

e) puskesmas pembantu dan balai pengobatan, yang berfungsi sebagai unit pelayanan kesehatan sederhana yang memberikan pelayanan kesehatan terbatas dan membantu pelaksanaan kegiatan puskesmas dalam lingkup wilayah yang lebih kecil;

f) tempat praktek dokter, merupakan salah satu sarana yang memberikan pelayanan kesehatan secara individual dan lebih dititikberatkan pada usaha penyembuhan tanpa perawatan; dan

g) apotik, berfungsi untuk melayani penduduk dalam pengadaan obat-obatan, baik untuk penyembuhan maupun pencegahan.

\section{Tabel 2.7 Kebutuhan sarana kesehatan}




\begin{tabular}{|c|c|c|c|c|c|c|c|c|}
\hline \multirow[b]{2}{*}{ No. } & \multirow[b]{2}{*}{$\begin{array}{l}\text { Jenis } \\
\text { Sarana }\end{array}$} & \multirow{2}{*}{$\begin{array}{l}\text { Jumlah } \\
\text { Penduduk } \\
\text { pendukung } \\
\text { (jiwa) }\end{array}$} & \multicolumn{2}{|c|}{$\begin{array}{l}\text { Kebutuhan Per } \\
\text { Satuan Sarana }\end{array}$} & \multirow[b]{2}{*}{$\begin{array}{l}\text { Standard } \\
\left(\mathrm{m}^{2} / \mathrm{j} \mathbf{w a}\right)\end{array}$} & \multicolumn{2}{|c|}{ Kriteria } & \multirow[b]{2}{*}{ Keterangan } \\
\hline & & & $\begin{array}{l}\text { Luas } \\
\text { Lantai } \\
\text { Min. } \\
\left(\mathrm{m}^{2}\right) \\
\end{array}$ & $\begin{array}{l}\text { Luas } \\
\text { Lahan } \\
\text { Min. } \\
\left(\mathrm{m}^{2}\right) \\
\end{array}$ & & $\begin{array}{c}\text { Radius } \\
\text { pencapaian }\end{array}$ & $\begin{array}{l}\text { Lokasi dan } \\
\text { Penyelesaian }\end{array}$ & \\
\hline$\overline{1 .}$ & Posyandu & 1.250 & 36 & 60 & 0,048 & 500 & $\begin{array}{l}\text { Di tengah ke- } \\
\text { lompok } \\
\text { tetangga tidak } \\
\text { menyeberang } \\
\text { jalan raya. }\end{array}$ & $\begin{array}{l}\text { Dapat berga- } \\
\text { bung dengan } \\
\text { balai warga } \\
\text { atau sarana } \\
\text { hunian/rumah }\end{array}$ \\
\hline 2. & $\begin{array}{l}\text { Balai } \\
\text { Pengobatan } \\
\text { Warga }\end{array}$ & 2.500 & 150 & 300 & 0,12 & $1.000 \mathrm{~m}^{\prime}$ & $\begin{array}{l}\text { Di tengah } \\
\text { kelompok } \\
\text { tetangga tidak } \\
\text { menyeberang } \\
\text { jalan raya. }\end{array}$ & $\begin{array}{l}\text { Dapat } \\
\text { bergabung } \\
\text { dalam lokasi } \\
\text { balai warga }\end{array}$ \\
\hline 3. & $\begin{array}{l}\text { BKIA / Klinik } \\
\text { Bersalin }\end{array}$ & 30.000 & 1.500 & 3.000 & 0,1 & $4.000 \mathrm{~m}^{\prime}$ & $\begin{array}{l}\text { Dapat } \\
\text { dijangkau } \\
\text { dengan } \\
\text { kendaraan } \\
\text { umum }\end{array}$ & \\
\hline 4. & $\begin{array}{l}\text { Puskesmas } \\
\text { Pembantu } \\
\text { dan Balai } \\
\text { Pengobatan } \\
\text { Lingkungan }\end{array}$ & 30.000 & 150 & 300 & 0,006 & $1.500 \mathrm{~m}^{\prime}$ & -idem- & $\begin{array}{l}\text { Dapat berg- } \\
\text { bung dalam } \\
\text { lokasi kantor } \\
\text { kelurahan }\end{array}$ \\
\hline 5. & $\begin{array}{l}\text { Puskesmas } \\
\text { dan Balai } \\
\text { Pengobatan }\end{array}$ & 120.000 & 420 & 1.000 & 0,008 & $3.000 \mathrm{~m}^{\prime}$ & -idem- & $\begin{array}{l}\text { Dapat } \\
\text { bergabung } \\
\text { dalam lokasi } \\
\text { kantor } \\
\text { kecamatan }\end{array}$ \\
\hline 6. & $\begin{array}{l}\text { Tempat } \\
\text { Praktek } \\
\text { Dokter }\end{array}$ & 5.000 & 18 & - & - & $1.500 \mathrm{~m}^{\prime}$ & -idem- & $\begin{array}{l}\text { Dapat bersatu } \\
\text { dengan rumah } \\
\text { tinggal/tempat }\end{array}$ \\
\hline 7. & $\begin{array}{l}\text { Apotik / } \\
\text { Rumah } \\
\text { Obat }\end{array}$ & 30.000 & 120 & 250 & 0,025 & $1.500 \mathrm{~m}^{\prime}$ & -idem- & usaha/apotik \\
\hline
\end{tabular}

CATATAN Acuan diambil dari SNI 03-1733-1989, Tata cara perencanaan kawasan perumahan kota. 


\section{BAB III \\ PEMBAHASAN}

\subsection{Gambaran Umum Wilayah (Telluwanua Kota Palopo)}

Telluwanua adalah sebuah kecamatan di Kota Palopo, Sulawesi

Selatan, Indonesia. Telluwanua terletak di Kota Palopo, Sulawesi Selatan.

Telluwanua adalah kecamatan yang unik (bersama dengan 9 kecamatan, yaitu Kecamatan Wara Selatan, Kecamatan Wara Timur, Kecamatan Bara, Kecamatan Sendana, Kecamatan Mungkajang, Kecamatan Telluwanua, Kecamatan Wara, Kecamatan Wara Utara, dan Kecamatan Wara Barat) di karenakan induk ibu kota kabupatennya berada di antara kota/kabupaten yang lain, jarak antara ibu kota kabupaten dengan kecamatan ini cukup jauh yaitu sekitar $100 \mathrm{Km}$ dan harus melewati 1 kota yang lain untuk menempuhnya. di tempuh dalam waktu 2 jam.

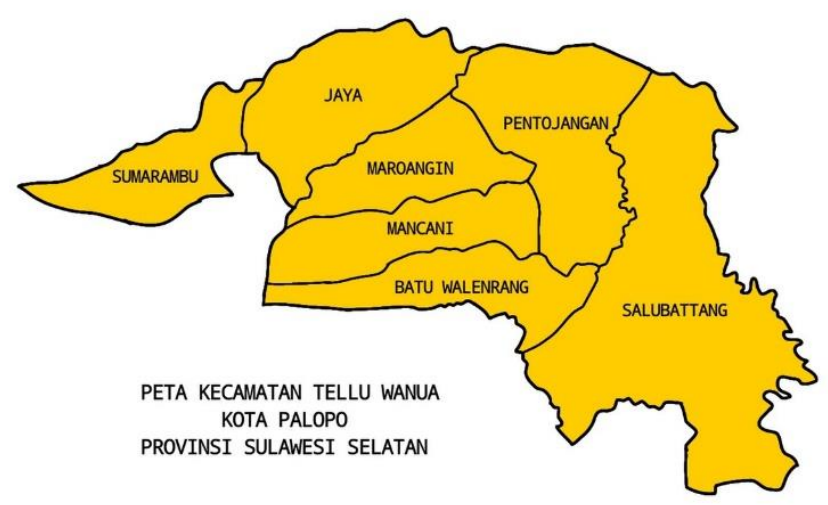

Gambar 3.1 Sketsa Peta Kecamatan Telluwanua

\subsection{Jumlah penduduk 5 tahun terakhir}

Tabel 3.1 Jumlah penduduk 5 tahun terakhir 


\begin{tabular}{|c|c|c|c|c|c|c|}
\hline No & KECAMATAN & 2016 & 2017 & 2018 & 2019 & 2020 \\
\hline 1 & Telluwanua & 13028,000 & 13.328 & 13.614 & 13.911 & 15.887 \\
\hline
\end{tabular}

\subsection{Jumlah Fasilitas Pendidikan, Ekonomi dan Kesehatan.}

\subsubsection{Fasilitas pendidikan}

Tabel 3.2 Jumlah fasilitas pedidikan

\begin{tabular}{|c|c|c|}
\hline No & JENIS FASILITAS & JUMLAH \\
\hline 1 & SD & 7 \\
\hline 2 & SMP & 5 \\
\hline 3 & SMA & 1 \\
\hline
\end{tabular}

3.3.2 Fasilitas ekonomi

Tabel 3.3 Jumlah fasilitas ekonomi

\begin{tabular}{|c|c|c|}
\hline No & JENIS FASILITAS & JUMLAH \\
\hline 1 & PUSTU & 4 \\
\hline 2 & PUSKESMAS & 1 \\
\hline 3 & RUMAH SAKIT & 0 \\
\hline
\end{tabular}

3.3.3 Fasilitas kesehatan

Tabel 3.4 Jumlah fasilitas kesehatan

\begin{tabular}{|c|c|c|}
\hline No & JENIS FASILITAS & JUMLAH \\
\hline 1 & WARUNG & 22 \\
\hline 2 & PERTOKOAN & 187 \\
\hline 3 & PASAR & 0 \\
\hline
\end{tabular}


3.4 Proyeksi Penduduk 20 Tahun Yang Akan Datang (2025, 2030, 2035, 2040)

Tabel 3.5 Proyeksi penduduk 20 tahun yang akan datang

\begin{tabular}{|c|c|c|c|c|c|c|}
\hline No & KECAMATAN & RASIO & 2025 & 2030 & 2035 & 2040 \\
\hline 1 & Telluwanua & 0,142 & 27.170 & 38.454 & 49.737 & 61.021 \\
\hline
\end{tabular}

3.5 Kebutuhan Sarana dan Prasarana 20 Tahun Yang Akan Datang (2025, 2030, 2035, 2040)

\subsubsection{Sarana Pendidikan}

1) Tahun 2025

Tabel 3.6 Kebutuhan sarana pendidikan ditahun 2025

\begin{tabular}{|c|c|c|c|c|c|c|}
\hline No & $\begin{array}{c}\text { SARANA } \\
\text { PENDIDIKAN }\end{array}$ & $\begin{array}{c}\text { JUMLAH } \\
\text { SARANA }\end{array}$ & $\begin{array}{c}\text { JUMLAH } \\
\text { PENDUDUK } \\
\text { TAHUN } \\
\mathbf{2 0 2 5}\end{array}$ & $\begin{array}{c}\text { JUMLAH } \\
\text { PENDUDUK } \\
\text { PENDUKUNG }\end{array}$ & $\begin{array}{c}\text { KEBUTUHAN } \\
\text { BERDASARKAN } \\
\text { SNI }\end{array}$ & PENAMBAHAN \\
\hline 1 & SD & 7 & \multirow{2}{*}{27.170} & 1.600 & 17 & 10 \\
\hline 2 & SMP & 5 & 4.800 & 6 & 1 \\
\hline 3 & SMA & 1 & & 4.800 & 6 & 5 \\
\cline { 1 - 1 } & & & &
\end{tabular}

CATATAN Acuan diambil dari SNI 03-1733-1989, Tata cara perencanaan kawasan perumahan kota.

2) Tahun 2030

Tabel 3.7 Kebutuhan sarana pendidikan ditahun 2030

\begin{tabular}{|c|c|c|c|c|c|c|}
\hline No & $\begin{array}{c}\text { SARANA } \\
\text { PENDIDIKAN }\end{array}$ & $\begin{array}{c}\text { JUMLAH } \\
\text { SARANA }\end{array}$ & $\begin{array}{c}\text { JUMLAH } \\
\text { PENDUDUK } \\
\text { TAHUN } \\
\mathbf{2 0 3 0}\end{array}$ & $\begin{array}{c}\text { JUMLAH } \\
\text { PENDUDUK } \\
\text { PENDUKUNG }\end{array}$ & $\begin{array}{c}\text { KEBUTUHAN } \\
\text { BERDASARKAN } \\
\text { SNI }\end{array}$ & PENAMBAHAN \\
\hline 1 & SD & 7 & & 1.600 & 24 & 17 \\
\hline 2 & SMP & 5 & \multirow{2}{*}{38.454} & 4.800 & 8 & 3 \\
\hline 3 & SMA & 1 & & 4.800 & 8 & 7 \\
\cline { 1 - 1 } & & & &
\end{tabular}

CATATAN Acuan diambil dari SNI 03-1733-1989, Tata cara perencanaan kawasan perumahan kota. 
3) Tahun 2035

Tabel 3.8 Kebutuhan sarana pendidikan ditahun 2035

\begin{tabular}{|c|c|c|c|c|c|c|}
\hline No & $\begin{array}{c}\text { SARANA } \\
\text { PENDIDIKAN }\end{array}$ & $\begin{array}{l}\text { JUMLAH } \\
\text { SARANA }\end{array}$ & $\begin{array}{l}\text { JUMLAH } \\
\text { PENDUDUK } \\
\text { TAHUN } \\
2035\end{array}$ & $\begin{array}{c}\text { JUMLAH } \\
\text { PENDUDUK } \\
\text { PENDUKUNG }\end{array}$ & $\begin{array}{c}\text { KEBUTUHAN } \\
\text { BERDASARKAN } \\
\text { SNI }\end{array}$ & PENAMBAHAN \\
\hline 1 & SD & 7 & \multirow{3}{*}{49.737} & 1.600 & 31 & 24 \\
\hline 2 & SMP & 5 & & 4.800 & 10 & 5 \\
\hline 3 & SMA & 1 & & 4.800 & 10 & 9 \\
\hline
\end{tabular}

CATATAN Acuan diambil dari SNI 03-1733-1989, Tata cara perencanaan kawasan perumahan kota.

4) Tahun 2040

Tabel 3.9 Kebutuhan sarana pendidikan ditahun 2040

\begin{tabular}{|c|c|c|c|c|c|c|}
\hline No & $\begin{array}{c}\text { SARANA } \\
\text { PENDIDIKAN }\end{array}$ & $\begin{array}{c}\text { JUMLAH } \\
\text { SARANA }\end{array}$ & $\begin{array}{c}\text { JUMLAH } \\
\text { PENDUDUK } \\
\text { TAHUN } \\
\mathbf{2 0 4 0}\end{array}$ & $\begin{array}{c}\text { JUMLAH } \\
\text { PENDUDUK } \\
\text { PENDUKUNG }\end{array}$ & $\begin{array}{c}\text { KEBUTUHAN } \\
\text { BERDASARKAN } \\
\text { SNI }\end{array}$ & PENAMBAHAN \\
\cline { 1 - 1 } 1 & SD & 7 & \multirow{2}{*}{61.021} & 1.600 & 38 & 31 \\
\hline 2 & SMP & 5 & 4.800 & 13 & 8 \\
\hline 3 & SMA & 1 & & 4.800 & 13 & 12 \\
\hline
\end{tabular}

CATATAN Acuan diambil dari SNI 03-1733-1989, Tata cara perencanaan kawasan perumahan kota.

\subsubsection{Sarana ekonomi}

1) Tahun 2025

Tabel 3.10 Kebutuhan sarana ekonomi ditahun 2025

\begin{tabular}{|c|c|c|c|c|c|c|}
\hline No & $\begin{array}{c}\text { SARANA } \\
\text { EKONOMI }\end{array}$ & $\begin{array}{c}\text { JUMLAH } \\
\text { SARANA }\end{array}$ & $\begin{array}{c}\text { JUMLAH } \\
\text { PENDUDUK } \\
\text { TAHUN } \\
2025\end{array}$ & $\begin{array}{c}\text { JUMLAH } \\
\text { PENDUDUK } \\
\text { PENDUKUNG }\end{array}$ & $\begin{array}{c}\text { KEBUTUHAN } \\
\text { BERDASARKAN } \\
\text { SNI }\end{array}$ & PENAMBAHAN \\
\hline 1 & WARUNG & 22 & \multirow{2}{*}{27.170} & 250 & 109 & 87 \\
\hline 2 & PERTOKOAN & 187 & 6.000 & 5 & 0 \\
\hline 3 & PASAR & 0 & & 30.000 & 1 & 1 \\
\cline { 1 - 1 }
\end{tabular}


2) Tahun 2030

Tabel 3.11 Kebutuhan sarana ekonomi ditahun 2030

\begin{tabular}{|c|c|c|c|c|c|c|}
\hline No & $\begin{array}{l}\text { SARANA } \\
\text { EKONOMI }\end{array}$ & $\begin{array}{l}\text { JUMLAH } \\
\text { SARANA }\end{array}$ & $\begin{array}{l}\text { JUMLAH } \\
\text { PENDUDUK } \\
\text { TAHUN } \\
2030\end{array}$ & $\begin{array}{c}\text { JUMLAH } \\
\text { PENDUDUK } \\
\text { PENDUKUNG }\end{array}$ & $\begin{array}{c}\text { KEBUTUHAN } \\
\text { BERDASARKAN } \\
\text { SNI }\end{array}$ & PENAMBAHAN \\
\hline 1 & WARUNG & 22 & \multirow{3}{*}{38.454} & 250 & 154 & 132 \\
\hline 2 & PERTOKAN & 187 & & 6.000 & 6 & 0 \\
\hline 3 & PASAR & 0 & & 30.000 & 1 & 1 \\
\hline
\end{tabular}

3) Tahun 2035

Tabel 3.12 Kebutuhan sarana ekonomi ditahun 2035

\begin{tabular}{|c|c|c|c|c|c|c|}
\hline No & $\begin{array}{c}\text { SARANA } \\
\text { EKONOMI }\end{array}$ & $\begin{array}{c}\text { JUMLAH } \\
\text { SARANA }\end{array}$ & $\begin{array}{c}\text { JUMLAH } \\
\text { PENDUDUK } \\
\text { TAHUN } \\
\mathbf{2 0 3 5}\end{array}$ & $\begin{array}{c}\text { JUMLAH } \\
\text { PENDUDUK } \\
\text { PENDUKUNG }\end{array}$ & $\begin{array}{c}\text { KEBUTUHAN } \\
\text { BERDASARKAN } \\
\text { SNI }\end{array}$ & PENAMBAHAN \\
\cline { 1 - 1 } 1 & WARUNG & 22 & \multirow{2}{*}{49.737} & 250 & 199 & 177 \\
\hline 2 & PERTOKOAN & 187 & 6.000 & 0 & 0 \\
\hline 3 & PASAR & 0 & & 30.000 & 0 & 0 \\
\hline
\end{tabular}

4) Tahun 2040

Tabel 3.13 Kebutuhan sarana ekonomi ditahun 2040

\begin{tabular}{|c|c|c|c|c|c|c|}
\hline No & $\begin{array}{c}\text { SARANA } \\
\text { EKONOMI }\end{array}$ & $\begin{array}{c}\text { JUMLAH } \\
\text { SARANA }\end{array}$ & $\begin{array}{c}\text { JUMLAH } \\
\text { PENDUDUK } \\
\text { TAHUN } \\
\mathbf{2 0 4 0}\end{array}$ & $\begin{array}{c}\text { JUMLAH } \\
\text { PENDUDUK } \\
\text { PENDUKUNG }\end{array}$ & $\begin{array}{c}\text { KEBUTUHAN } \\
\text { BERDASARKAN } \\
\text { SNI }\end{array}$ & PENAMBAHAN \\
\hline 1 & WARUNG & 22 & \multirow{2}{*}{61.021} & 250 & 244 & 222 \\
\hline 2 & PERTOKOAN & 187 & 6.000 & 0 & 0 \\
\hline 3 & PASAR & 0 & & 30.000 & 0 & 0 \\
\hline
\end{tabular}




\subsubsection{Sarana kesehatan}

1) Tahun 2025

Tabel 3.14 Kebutuhan sarana kesehatan ditahun 2025

\begin{tabular}{|c|c|c|c|c|c|c|}
\hline No & $\begin{array}{c}\text { SARANA } \\
\text { KESEHATAN }\end{array}$ & $\begin{array}{c}\text { JUMLAH } \\
\text { SARANA }\end{array}$ & $\begin{array}{c}\text { JUMLAH } \\
\text { PENDUDUK } \\
\text { TAHUN } \\
\mathbf{2 0 2 5}\end{array}$ & $\begin{array}{c}\text { JUMLAH } \\
\text { PENDUDUK } \\
\text { PENDUKUNG }\end{array}$ & $\begin{array}{c}\text { KEBUTUHAN } \\
\text { BERDASARKAN } \\
\text { SNI }\end{array}$ & PENAMBAHAN \\
\hline 1 & PUSTU & 4 & & 30.000 & 1 & 0 \\
\cline { 1 - 2 } 2 & PUSKESMAS & 1 & \multirow{2}{*}{27.170} & 120.000 & 0 & 0 \\
3 & $\begin{array}{c}\text { RUMAH } \\
\end{array}$ & 0 & & & & \\
\hline
\end{tabular}

2) Tahun 2030

Tabel 3.15 Kebutuhan sarana kesehatan ditahun 2030

\begin{tabular}{|c|c|c|c|c|c|c|}
\hline No & $\begin{array}{c}\text { SARANA } \\
\text { KESEHATAN }\end{array}$ & $\begin{array}{c}\text { JUMLAH } \\
\text { SARANA }\end{array}$ & $\begin{array}{c}\text { JUMLAH } \\
\text { PENDUDUK } \\
\text { TAHUN } \\
\mathbf{2 0 3 0}\end{array}$ & $\begin{array}{c}\text { JUMLAH } \\
\text { PENDUDUK } \\
\text { PENDUKUNG }\end{array}$ & $\begin{array}{c}\text { KEBUTUHAN } \\
\text { BERDASARKAN } \\
\text { SNI }\end{array}$ & PENAMBAHAN \\
\cline { 1 - 2 } 1 & PUSTU & 4 & & 30.000 & 1 & 0 \\
\hline 2 & PUSKESMAS & 1 & \multirow{2}{*}{38.454} & 120.000 & 0 & 0 \\
\cline { 1 - 2 } 3 & $\begin{array}{c}\text { RUMAH } \\
\end{array}$ & 0 & & & & \\
\hline
\end{tabular}

3) Tahun 2035

Tabel 3.16 Kebutuhan sarana kesehatan ditahun 2035

\begin{tabular}{|c|c|c|c|c|c|c|}
\hline 、 & $\begin{array}{c}\text { SARANA } \\
\text { KESEHATAN }\end{array}$ & $\begin{array}{l}\text { JUMLAH } \\
\text { SARANA }\end{array}$ & $\begin{array}{c}\text { JUMLAH } \\
\text { PENDUDUK } \\
\text { TAHUN } \\
\mathbf{2 0 3 5}\end{array}$ & $\begin{array}{c}\text { JUMLAH } \\
\text { PENDUDUK } \\
\text { PENDUKUNG }\end{array}$ & $\begin{array}{c}\text { KEBUTUHAN } \\
\text { BERDASARKAN } \\
\text { SNI }\end{array}$ & PENAMBAHAN \\
\hline 1 & PUSTU & 4 & \multirow{3}{*}{49.737} & 30.000 & 2 & 0 \\
\hline 2 & PUSKESMAS & 1 & & 120.000 & 0 & 0 \\
\hline 3 & $\begin{array}{c}\text { RUMAH } \\
\text { SAKIT }\end{array}$ & 0 & & & & \\
\hline
\end{tabular}


4) Tahun 2040

Tabel 3.17 Kebutuhan sarana kesehatan ditahun 2040

\begin{tabular}{|c|c|c|c|c|c|c|}
\hline C & $\begin{array}{c}\text { SARANA } \\
\text { KESEHATAN }\end{array}$ & $\begin{array}{l}\text { JUMLAH } \\
\text { SARANA }\end{array}$ & $\begin{array}{c}\text { JUMLAH } \\
\text { PENDUDUK } \\
\text { TAHUN } \\
2040\end{array}$ & $\begin{array}{c}\text { JUMLAH } \\
\text { PENDUDUK } \\
\text { PENDUKUNG }\end{array}$ & $\begin{array}{c}\text { KEBUTUHAN } \\
\text { BERDASARKAN } \\
\text { SNI }\end{array}$ & PENAMBAHAN \\
\hline 1 & PUSTU & 4 & \multirow{3}{*}{61.021} & 30.000 & 2 & 0 \\
\hline 2 & PUSKESMAS & 1 & & 120.000 & 1 & 0 \\
\hline 3 & RUMAH SAKIT & 0 & & & & \\
\hline
\end{tabular}




\section{BAB IV \\ PENUTUP}

\subsection{Kesimpulan}

4.1.1 Ketersediaan sarana pendidikan di Kecamatan Telluwanua pada saat ini umumnya telah memadai, dan juga terutama untuk sarana perdagangan \& niaga.

4.1.2 Kebutuhan sarana permukiman di Kecamatan Telluwanua untuk 20 tahun kedepan sangat diperlukan. Minimnya ketersediaan sarana kesehatan dan pertumbuhan jumlah pelajar, maka fasilitas seperti posyandu dan sekolah sangat diperlukan di Kecamatan ini.

\subsection{Saran}

4.2.1 Perlu adanya perhatian dari pemerintah untuk sarana yang belum tersedia di Kecamatan Telluwanua khususnya sarana kesehatan dan infrastruktur lainnya. Dengan ketersediaan kebutuhan fasilitas tersebut, diharapakan pelayananya dapat menjangkau seluruh lingkungan permukiman yang ada di kecamatan Telluwanua

4.2.2 Perlu adanya evaluasi dari pemerintah untuk sarana kesehatan di Kecamatan Telluwanua yang tidak merata antara satu Kelurahan dengan kelurahan lainnya.

4.2.3 Menurut penulis berdasarkan infrastruktur dan sarana baik kesehatan maupun lalu lintas kecamatan Telluwanua perlu dapat perhatian lebih dari pemerintah dikarenakan minimnya ketersediaan sarana Walenrang. 


\section{DAFTAR PUSTAKA}

Fisu, A. A., \& Didiharyono, D. (2020, April). Economic \& Financial Feasibility Analysis of Tarakan Fishery Industrial Estate Masterplan. In IOP Conference Series: Earth and Environmental Science (Vol. 469, No. 1, p. 012002). IOP Publishing.

Fisu, A. A., \& Marzaman, L. U. (2018). Pemetaan Partisipatif Kampung Pesisir Kelurahan Tallo Kota Makassar. To Maega: Jurnal Pengabdian Masyarakat, 1(1), 22-28.

https://adoc.pub/bab-i-pendahuluan-suatu-daerah-pertumbuhan-ekonomi-yangberk.html

http://repository.unpas.ac.id/32601/2/BAB\%20Il.pdf

http://nawasis.org/portal/download/digilib/369-SNI-2004 1733 03.pdf

https://luwukab.bps.go.id/publication/2021/09/24/79da5557c2ef938dc747c1e6/ke camatan-walenrang-dalam-angka-2021.html

https://ciptakarya.pu.go.id/dok/hukum/kepmen/kepmen 534 2001.pdf http://ditpsd.kemdikbud.go.id/upload/filemanager/2020/10/Lampiran\%20Permen\% 2024\%202007\%20Standar\%20Sarana\%20Prasarana.pdf

https://dspace.uii.ac.id/bitstream/handle/123456789/3141/05.2\%20bab\%202.pdf? sequence=6\&isAl

https://www.google.com/search?q=Kebutuhan+ruang+belajar+pada+SD\%2FMl\% 2C+SLTP\%2FMTs+\%26+SMU\&oq=Kebutuhan+ruang+belajar+pada+SD\%2FMI \%2C+SLTP\%2FMTs+\%26+SMU\&aqs=chrome..69i57.1238j0j9\&sourceid=chrome $\underline{\text { ie }=\mathrm{UTF}-8}$

https://palopokota.go.id/content/uploads/data/dokumen-perencanaan/12.-RKPD2020.pdf 
https://www.slideshare.net/dekpian/sni-03-17332004-v2-tata-cara-perencanaanlingkungan-perumahan-di-perkotaan

https://sippa.ciptakarya.pu.go.id/sippa online/ws file/dokumen/rpi2jm/DOCRPIJM 1478843189BAB 6 PROFIL KOTA PALOPO.pdf

https://palopokota.bps.go.id/

https://palopokota.bps.go.id/indicator/30/129/1/jumlah-fasilitas-kesehatanmenurut-kecamatan.html

https://www.google.com/search?q=Kebutuhan+Sarana+dan+Prasarana+20+Tahu $\underline{\mathrm{n}+\text { Yang }+ \text { Akan+Datang+palopo\&oq=Kebutuhan }+ \text { Sarana+dan+Prasarana }+20+\text { Tah }}$ $\underline{\text { un+Yang+Akan+Datang }+ \text { palopo\&aqs=chrome..69i57.3542j0j4\&sourceid=chrome }}$ $\underline{\text { \&ie }=\text { UTF-8 }}$

https://www.nomor.net/ kodepos.php? i=desakodepos\&sby=000000\&daerah=Kecamatan - Kota-Palopo\&jobs=Telluwanua https://peta.web.id/peta/kec/telluwanua-385 